\title{
Cross-Cultural Classroom Interaction between Native and Non-native Speakers of English
}

\author{
Ms. Hanaa Alzalouk ${ }^{1}$
}

Faculty of Arts, Misurata University

https://doi.org/10.36602/faj.2018.n12.12

\section{Abstract}

The purpose of this study was to investigate the interactional conversations between the native speakers (NSs) of English and the non-native speakers (NNSs) of English in a culturally mixed classroom. ESL learners need to be exposed to the second language through authentic and face to face interaction when they have opportunities to interact with NSs outside of the classroom (in real-life situations) and inside the classroom (through group work and pair work activities). Data were collected through conducting an ethnographic research in which classroom observation and semistructured interviews were the primary data collection tools. Participants were eight MA students in the field of English Language Teaching (ELT) in Nottingham Trent University.

Results indicated that the participants need to improve cultural awareness and communication skills. In addition, NSs showed that they are willing to join a group work with NNSs as they can learn about other cultures, but in some cases, they find this tiring when the NNSs fail to participate due to certain factors. This might be due to language problems or little knowledge about the topic being discussed.

Keywords: Native Speakers; Non-Native Speakers; Classroom Interaction; Culturally Mixed Classrooms; Ethnographic Research; Cultural Awareness.

h.alzalouk@art.misuratau.edu.ly ${ }^{1}$ 


$$
\text { ملخص البحث }
$$

تمدف هذه الدراسة لبحث المحادثات التفاعلية بين المتحدثين باللغة الانجليزية كلغة أم مع من لا تعد اللغة الانجليزية لغتهم الأصلية داخل الفصول الدراسية المختلطة ثقافيا. الطلبة الدارسين اللغة الانجليزية كلغة ثانية ينبغي أن يتعرضوا للغة الانجليزية من خلال التواصل الحقيقي والمباشر حين تتاح لمم فرصة التعامل مع الناطقين باللغة الانجليزية كلغة أصلية خارج الفصل الدراسي (الحياة الواقعية) وداخل الفصل الدراسي (من خلال أنشطة العمل الثنائية والجماعية). تم جمع البيانات عن طريق إجراء بحث اثنوغرافي حيث كانت ملاحظة الباحث لسلوك الطالاب داخل الفصل الدراسي وإجراء مقابلات معهم الوسائل الرئيسية لجمع البيانات. كان عدد المشاركين في هذه الدراسة البحثية ثمانية من طلاب درجة الماجستير في بجال تعليم اللغة الانجليزية في جامعة نوتنغهام ترنت البريطانية. أظهرت النتائج أن المشاركين في حاجة لتحسين الوعي الثقافي ورفع مهارات التواصل. بالإضافة إلى ذلك، تبين أن الطلبة المتحدثين باللغة الانجليزية كلغة أم راغبون في الانضمام لأنشطة العمل الجماعي مع زمائهم حيث بإمكاهم التعرف على ثقافات الآخرين، ولكن. في بعض الحالات يجمدون ذلك متعبا عندما يعجز زمالئهم (ممن لا يتحدثون اللغة الانجليزية كلغة أم) عن المشاركة في النشاط الجماعي. قد يكون ذلك نتيجة أهم يعانون من مشاكل لغوية أو معرفة محدودة عن الموضوع المناقش.

\section{Introduction}


The nature of classroom interaction has become the topic of many researches recently (Freiermuth, 2001; Long \& Porter, 1985). When the focus of this topic is on a culturally mixed classroom (international students), the common question is "Who takes the dominant part in conversations between native speakers of English (NSs) and non-native speakers of English (NNSs) in classroom settings". Summers \& Volet (2008) state that when the university campus is international, students' intercultural competence and confidence can be improved. This is a result of the interaction between students from different cultural backgrounds either inside or outside the classroom. This paper investigates the behavior of the native speakers of English towards the non-native speakers of English and sheds light on who talks more in interactional conversations inside a classroom.

\subsection{Classroom Interaction and ESL Learning}

Interaction inside classrooms has been defined as the fundamental part of classroom activities as everything occurs in the classroom through a procedure of live person-person interaction (Allwright, 1984, as cited in Ellis, 1994). This point of view has drawn seriously on research and theories dealing with the relationship between interaction and second language learning. These theories have encouraged the necessity of being exposed to the second language as 'authentic' and natural language (Mori, 2002), for that reason the chances for ESL (English as a Second Language) learners to be involved into real-life interaction have been privileged over the teacher-fronted controlled practice.

Lightbown \& Spada (2006) point out that classroom interaction refers to the conversational relationship between the teacher and the student and between the students themselves. This conversational relationship can be accomplished when the students work in pairs and in groups. Interactional group work, as Ellis (1994) 
suggests, can play a major role in promoting second language learning. Classes where students have opportunities to communicate with each other (Summers \& Volet, 2008) help students discuss ideas in small groups and may support a whole class discussion.

\subsection{Cross-Cultural Classroom Interaction (NSs and NNSs of English)}

Many NNSs are students of international universities which can be a perfect setting for interacting with NSs. Nonetheless, it is not usually an uncomplicated task for some NNS students to engage with their NS peers because, in Freiermuth's (2001) point of view, they might fail to act together with NSs due to certain factors as fear, embarrassment, anxiety, and misapprehension. The purpose behind studying classroom interaction between NSs and NNSs of English in the mixed culture classroom is a belief that, as Kramsch (1998) states, language and culture are 'two sides of the same coin'. In other words, because it is a means of interaction, language is a part of culture and culture is a part of language. For that reason it is believed that an individual's language reflects his/her own culture when he/she interacts with people from other cultures. In order to decrease miscomprehension among cross-cultural students ( $\mathrm{Su}, 2008)$ culture awareness should be raised, consequently, the cross-cultural interaction can be easier if the NNS and NS peers have certain necessary skills such as, knowledge of other cultures, language skills that can increase the chances to promote the cross-cultural interaction, and "...knowledge of how to move about in another culture and an ability to pursue one's interest" (Freiermuth, 2001, p.170)

Samovar \& Porter (2004) have highlighted several key issues on which students in a multicultural classroom (international students) should focus. One of these issues is that students from different backgrounds should raise the awareness of each other's cultures. As FitzGerald (2003) points out, in order to be successful communicators, 
non-native speakers need to be aware of what native speakers consider to be good communication in English. Awareness of other people's culture was one of the questions of the current research interviews and the participants have strongly recommended that there should be more awareness among cultures.

\subsection{NSs vs. NNSs of English}

Since the main aim in the present study is to investigate who talks more in the classroom group work and conversations between NSs and NNSs of English, a definition of the 'native speaker' is needed. Kramsch (1998, p.130) points out that the native speaker of a language is seen as "a person who is recognized, linguistically and culturally, by members of a discourse community as being one of them". Davies (1991, as cited in Cook, 1999) suggests that an individual is assumed to be a native speaker of the first language which is learnt in childhood. Non-native speakers, on the other hand, whose first language is not English, are often said to be 'bilingual' (Adkins, 1969). Another definition is expressed by Davies (2003, p. 213) who suggests that "to be a native speaker means not to be a nonnative speaker" which is, as Han (2004) believes, the most operational definition one may give to the concept of native speaker. He believes that it is easier to define a non-native speaker than a native speaker. The native speaker, as Han (2004) points out, should have a number of characteristics summarized as: (1) Native speakers acquire the first language (L1) of which they are NSs in childhood. (2) NSs have that exceptional competence in generating fluent natural utterance and writing creatively. (3) NSs are able to understand and interpret speech into their L1.

\subsection{General Findings}

Numerous research studies have been carried out to investigate the interactions in group work between NSs and NNSs of English in classrooms where students came from different cultures. Early on, 
Long and Porter (1985) indicated that there are several advantages which are attained when interaction is taking place between NSs and NNSs in the classroom. They argue that NNSs can become motivated to participate more when working in groups with NSs in classroom activities.

FitzGerald (2003) has conducted a research study investigating the interaction between native speakers of English (Australians) and non-native speakers of English (Chinese, Indians and Japanese). Her specific aim was to explore whether the claim that native speakers have an advantage over the non-native speaker is true, and whether the NSs tend to dominate the NNSs. The results of her study reveal that all the participants (who were a mix between NSs and NNSs) took quite long turns in the interaction, and everyone was given the chance to complete their turns. The NSs gave a chance to their NNS peers to be effectively involved in the interactivity. In the researcher's point of view, the NSs took their NNSs intercultural perspective into consideration. This study is one of several studies that FitzGerald has conducted inside the culturally mixed classrooms.

Another study was carried out by Nakane (2006) in which group work between native speakers of English (Australians) and nonnative speakers of English (Japanese) was observed. The main focus of this study was to investigate the silence of the Japanese students which the researcher frequently observed during group learning activities with native speakers of English. There are a variety of aspects, as Nakane argues, for the Japanese students' silence in an English group conversation, one of which is based on the cultural differences (e.g. in the Japanese culture, the students sometimes prefer to be silent in order to prevent 'face-losing'). In this study, the researcher also states that the Japanese students made reference to their silence in classroom communication by commenting that they do not like to talk much in the classroom. Moreover, some students explained that they would not speak unless they are nominated. 


\subsection{Objective of the Study}

The basic aim of this study is to look at the way native speakers of English behave towards non-native speakers of English in a classroom setting where there is a mixture of students from different cultural backgrounds (international students). The specific aspect is to explore who takes the leading role in the interaction of classroom group activities between native and non-native speakers of English.

\section{Methodology}

\subsection{Research Design}

In the current study, an ethnographic research was conducted. To begin with, the terminology should be clarified by defining the ethnographic research and identifying its characteristics. According to Newby (2010) the word ethnography comes from two Greek words: 'ethnos' that means 'people' or 'nation' and 'graphein' that means 'writing', that is to say ethnography is writing about people. Ethnography is a qualitative method which relies on 'close-up' personal experience, sometimes participation, and observation. Fetterman (1998) points out that ethnographic research involves the researcher to be close to the subjects observed (i.e. participants) in its natural situation, so that the results can be realistic and descriptive. When used as a method, ethnography is defined as "a written description of a particular culture - the customs, beliefs and behavior based on information collected through fieldwork" (Harris \& Johnson, 2000, p. 37).

Hammersley (1998) describes the ethnographic research as a method via which the researcher examines people's behavior in everyday context, observation is the main data collection tool, and interviews are used to clarify observations. Accordingly, the researcher needs to watch what happens, to listen to what is said, and to ask questions through formal and informal interviews (Grang \& 
Cook, 2007). Furthermore, the focus is usually on a small number of cases (a relatively small scale research). For ethical concerns, the participants were mentioned anonymously with informed consent.

\subsection{Context and Participants}

The context in which this study took place is the classroom setting, where the researcher could observe the way NSs and NNSs of English interact. The total number of participants was eight students from different cultures. Three native speakers of English (British) and five non-native speakers of English (three Libyan students, a Chinese student, and a Brazilian student). All of these students were doing their MA study in English Language Teaching (ELT) at Nottingham Trent University, Nottingham, UK.

\subsection{Research Instrument}

In this study the data were collected via two research methods; classroom observation and interviews, people were a primary data source. That is to say the primary data which were collected from people concerned what they say (Newby 2010) including direct answers to the questions which they were asked because "people's words are some of the richest data that we can have" (p. 149). Another issue in collecting primary data from people is to investigate what they $d o$, in other words the people's behavior inside the classroom. The behavior of the participants of this study (which I have noticed through classroom observation) was an equally important source of information.

\subsection{Procedure}

As indicated above, the data of this study have been collected by means of two research methods. The first one is the classroom observation which took place in an MA classroom. As Grang \& Cook (2007) explain; participant observation is the central way by which ethnographers have tried to understand the way of people's actual life 
in the context of their everyday lived experience. During the interviews the participants were audio recorded and I kept taking notes when needed. While observing the participants in their classroom their conversations were not recorded but rather I was taking as much 'field notes' as I could. Pole \& Morrison (2003, p.26) state that "field notes are key elements of participant observation and while it is rare to record too much, the importance of storing and organizing the writing as you proceed can never be underestimated". It is important here to mention that my observational approach has the characteristic of, as Newby (2010) calls it, being a 'natural setting'. In other words, the observation for this study has taken place in a natural location which is the classroom setting and I was a close observer. Also, I was an 'inactive and known' observer and this indicates that "... the observer is visibly an outsider to the group. The group is aware of the observer but has no interaction at a process level with them" (Newby, 2010, p. 367).

In addition to the classroom observation (in which the researcher observed eight participants), interviews were made with six participants (three NSs and three NNSs of English). According to Grang and Cook (2007, p.60) "along with participant observation, interviewing has been a primary means through which ethnographic researchers have attempted to get to grips with the contexts and contents of different people's lives". They argue that interviews in the ethnographic research can be treated as a separate method for the purpose that all social research involves making interviews. The interviews made in the current research study have taken place between individuals, that is between the interviewer and the interviewee, and not group interviews.

Typically, interviews in educational settings are divided into three main types; structured, semi-structured, and unstructured interviews (Newby 2010, Grang \& Cook 2006, Pole \& Morrison 2003). The first type is structured interviews in which the researcher 
has to prepare a number of questions and ask them in a fixed order. The second type of interviews is semi-structured interviews which are based on already prepared questions (often accompanied by follow-up why or how questions) which the researcher is aiming to cover. The third type is unstructured interviews where the researcher does not plan any questions in advance and leaves the interview to freely turn into a conversation. However, in this small scale research I used the second type of interviews because as Pole and Morrison (2003) point out, the educational ethnographic research is usually associated with semi-structured interviews which are assumed to have become a commonplace educational settings research. I found this helpful in conducting my interviews as if they were structured, I would not have the chance to ask follow-up questions nor would I be prepared to find a reply to participants' unexpected answers.

\section{Findings and Discussions}

The results of this research study are divided into two parts; the first of which is what has been concluded from the classroom observation. The second part is the results of the interviews with native speakers and non-native speakers in that culturally mixed classroom. The observed classroom was consisting of three NS students and five NNS students (three Libyans, a Chinese and Brazilian student). The participants were actively involved in more than one activity in which each one of them had to participate. The duration of the classroom observation was three hours. In fact in the first half of the lesson students were asked to work in groups of four while in the second half of the lesson students were asked to work in pairs. The first activity lasted for twenty minutes. It was observed that when working in groups NNS students participated less than the NS students did who had no choice but to talk. When asked to work together NNS students never initiated the conversation as if they assume that their NS peers are more competent than they are. Perhaps it was due to (as mentioned earlier) certain factors such as 
misunderstanding, anxiety, embarrassment, failure in communication or any other factor that may obviously affect the flow of conversation.

In another task the students were asked to work in pairs, where everyone had to mention an experience of their own about "culture shock". The instructor gave them a note that almost everyone had at least one culture shock in one's life. So each two students (NS and NNS) had to tell each other about their experience. It was obviously noted that everyone took an equal part and NNS students participated in the same way as NS students did.

There was an obvious difference in the way NNSs interact with their NS peers while doing group work and pair work activities. When students were organized to sit in groups, NNSs participated less and NSs almost did all of the work. However, when students were asked to work in pairs (a NS student with a NNS student) non-native speakers had no choice but to participate.

Interviews were made after taking notes from the classroom observation. When interviewing the NS students it was found out that their answers were to some extent similar. When the NSs were asked whether they like to talk more in group work with NNS students; one of the interviewee stated that when she works in a group with NNSs she interacts with them in the same way she does with NSs. In other words, she is happy with NNSs initiating the topic of the conversation and leading the group work. She added that she would rather welcome NNSs to participate and help them if they have language problems when interacting with her. She appreciates the NNS students' part taking in conversations with NS students by pointing out that "It always astonishes me how well the non-native speakers could cope with this course because for me I cannot cope with another language as efficiently as they do!".

The participant added that she usually finds it interesting to give the chance to her classmates who have come from different 
cultures to speak so that she can hear about their cultures. However, she pointed out that "there is a negative side as well to work with nonnative speakers" while telling a past experience of hers in a seminar group work where she was the only native speaker and the other three students were from China and Japan. She found that she did all the work and the other three students did nothing. She got an impression that in these students' own cultures they do not like to express their ideas nor do they like to argue for what they thought "anything I said they agreed with" she explained "so it was not a group work at all it was MY work!". This year the participant has made a conscious decision that she will work in a seminar with native speakers and that is not because she wants to exclude working with NNSs but simply because she needs to be working with people with whom she can argue. This was not that a bad experience for the participant but, as she claimed, it was somewhat tedious for her. A final point which the first interviewee mentioned is that she wonders why the NNSs prefer to sit in groups together and the NSs (including herself) prefer to sit in groups together and she argues that it is probably the human nature that assumes you sit with people you know and whom you can interact with.

The second interviewee was a native speaker as well. As soon as we started the interview; he stated that "I feel quite happy to join a group work with non-native speakers of English because when we work with people from different cultural backgrounds we can share different opinions and this makes the classroom quite interesting". Surprisingly, this participant pointed out that he has got even more respect for NNSs than the NSs when working in groups and this respect is shown through the way he slows down his speech in order to make it easy to be understood for the NNSs. He concludes his discussion by stating that "on the whole I usually exert myself to encourage NNSs to get actively involved when working in groups with NS peers". 
The answers of the third participant were not very different from the ones explained above. She stated that she sometimes finds it difficult to work in a group activity with NNS students and she is likely to dominate the conversation in just one case; when "they just would not say anything so I felt I had to do it". But she argued that she has experienced group work activities with some NNS students who were really competent and in fact "everybody took an equal part in the group work which was fair".

The interviews for this study were not conducted with students who are native speakers of English only; three NNS students were interviewed and asked them about their experiences in working in groups with NS students in a culturally mixed classroom. In fact most of the answers were different from each other and I guess it was due to individual differences (and maybe different social norms) between the interviewees. To begin with, the participants expressed that it is not all the NNS students are 'passive' in the classroom group work activities leaving the NS students to assume leadership in the conversation. The first participant expressed that "it is a good chance for me to share opinions, knowledge, and ideas when working in groups with students from different cultures... especially when working with NSs of English whom I can develop my oral skills with". This participant expressed that even if he feels that he is not able to say the appropriate words in group work with his NS classmates, he takes the risk of participating effectively in "an equal way that natives do". The answers of this interviewee were somewhat distinct from what the other two participants have said.

The second participant stated that she sometimes finds that it is not an easy task to work in groups with NS students in the language classroom explaining that the reason for this is her previous educational experience where she had a very little exposure to group work in the university system in her country. She further argued that "it seems that more awareness maybe needed of other countries 
educational systems because in my country I was only familiar with traditional ways of teaching in which the teacher stands in front of us and we sit in rows". This participant's statement reminded me of what Luk \& Lin (2007) argue that seating arrangements differ from one culture to another explaining that sitting in rows gives the students the thought that the lesson will be formal. However, when students are sitting around tables in semi or full circle shapes, they will feel more relaxed to participate in group activities.

The third participant whom I had interviewed has totally different responses from the first one. First he assumed that the nonparticipation he usually experiences when working in groups with NS students is due to language problems stating that "sometimes I cannot talk about all of my ideas because of limited vocabulary or sometimes, even though I want to participate I am usually unable to find the suitable words to say". He adds that he sometimes tends to be silent in group work with NS students because he is always afraid to say something wrong. The interviewee argues that in some cases he has no interest in the topic being discussed or simply he has no idea or knowledge of it, "in the classroom group work sometimes the teacher asks us to talk about a topic the NS students are familiar with but I have no idea about it".

\section{Conclusion and Recommendations}

\subsection{Conclusion}

This paper has highlighted the importance of interaction between NSs and NNSs of English in a culturally mixed classroom. It also discussed who takes the major role in group work and pair work activities and how NNS students find it difficult to get involved in classroom interaction. This difficulty might be a result of lack of knowledge of the topic being discussed or misunderstanding of NS students utterance. From the responses of the participants and classroom group and pair work observed, it was shown that NNS 
students preferred to be silent (or talk less) when working in groups with their NS peers. While they showed an obvious effort in interaction when they had a pair work task. NSs, on the other hand, were pleased to incorporate with NNSs in classroom activities unless their NNS peers were passive. NNSs explained that while crosscultural classroom interaction can be their perfect chance to learn the second language and know more about its culture, it was not always an easy task to work with NSs of English in groups. To sum up, cultural awareness should be raised so that students from different cultural backgrounds can put into consideration the cultural differences and distinct social norms.

\subsection{Recommendations}

The following recommendations are suggested;

1. Students should acquire cultural knowledge by studying national cultures.

2. Learning about the behaviors of different cultures relative to communication efficiently help to improve intercultural communication.

3. Students from different cultural backgrounds need to be involved in daily communication in order to learn and understand each others' cultures.

4. NNS students should not hesitate to participate in pairs and group work activities with their NS peers, even though they think they might make mistakes.

\section{References}

Adkins, P. G. (1969). Deficiency in comprehension in non-native speakers. TESOL Quarterly, 3(3), 197-201. 
Cook, V. (1999). Going beyond the native speaker in language teaching. TESOL Quarterly, 33(2), 185-210.

Davies, A. (2003). The Native Speaker in Applied Linguistics. Edinburgh: Edinburgh University Press.

Ellis, R. (1994). The Study of Second Language Acquisition. Oxford: Oxford University Press.

Fetterman, D. M. (1998). Ethnography: Step-by-Step. SAGE Publications.

Freiermuth, M. R. (2001). Native speakers or non-native speakers?

Who has the floor? On-line and face-to-face interaction in culturally mixed small groups. Computer Assisted Language Learning, 14(2), 169-199.

FitzGerald, H. (2003). How Different Are We? Spoken Discourse in Intercultural Communication. Frankfurt Lodge.

Grang, M. Cook, I. (2007). Doing Ethnographies. Rutledge.

Hammersley, M. (1998). Reading Ethnographic Research: A critical Guide. Harlow: Longman.

Han, Z. (2004). 'To be a native speaker means tot to be a nonnative speaker'. Second Language Research, 20(2), 166-187.

Harris, M. \& Johnson, O. (2003). Cultural Anthropology. Pearson Education Ltd.

Kramsch, C. (1998). Language and Culture. Oxford: Oxford University Press.

Kramsch, C. (1998). 'The privilege of the intercultural speaker. In Byram, M. \& Fleming, M. (eds.). Language Learning in Intercultural Perspective. Cambridge: Cambridge University Press. 
Lightbown, P. \& Spada, N. (2006). How Languages are Learned. Oxford: Oxford University Press.

Long, M. H. \& Porter, P. A. (1985). Group work, interlanguage talk, and second language acquisition. TESOL Quarterly, 19(2), 207228.

Luk, J. C. \& Lin, A. M. Y. (2007). Classroom Interactions as CrossCultural Encounters. Native Speakers in EFL Lessons. New Jersey.

Mori, J. (2002). Task design, plan, and development of task-ininteraction: an analysis of a small group activity in a Japanese language classroom. Applied Linguistics. 23(3), 323-347.

Nakane, I. (2006). Silence and politeness in intercultural communication in university seminars. Journal of Pragmatics, 38, 1811-1835.

Newby, P. (2010). Research Methods for Education. Harlow: Pearson Education Limited.

Pole, C. \& Morrison, M. (2003). Ethnography for Education. Berkshire: Open University Press.

Samovar, L. A. \& Porter R. E. (2004). Communication between Cultures. Thomson Learning Academic Resource Centre, USA.

Su, Y. (2008). Promoting cross-cultural awareness and understanding: incorporating ethnographic interviews in college EFL classes in Taiwan. Educational Studies, 34(4), 377-398.

Summers, M. \& Volet, S. (2008). Students attitudes towards culturally mixed groups on international campuses: impact of participation in diverse and non-diverse groups. Studies in Higher Education, 33(4), 357-370. 